\title{
Sabahattin Ali'nin Hikâyelerinde Yeni Bir İnsan Yaratma Alanı Olarak Eğitim
}

\author{
Education as a New Human Creation Field in Sabahattin Ali's Stories
}

\section{Yalçın ERGÜNEŞ *}

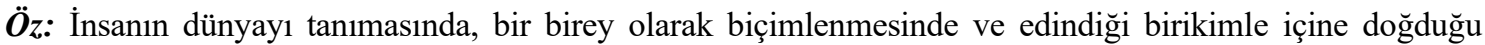
dünyaya katkı sağlamasında, eğitimin rolü tartışılmaz bir gerçektir. Kaldı ki, bütün uygar uluslarda, eğitim; ilerlemenin, kalkınmanın ve yaşanabilir yeni bir dünya yaratmanın önemli dinamiklerinden biri olarak kabul edilmektedir. Bu önemine dayalı olarak, bugün "uygar" kelimesiyle tanımladığımız batılı ulusların, sanayi, teknoloji faaliyetlerinden çok önce eğitim ve öğretim faaliyetlerini düzenledikleri ve hayata geçirdikleri de bilinmektedir. Bu bağlamda, tüm dünyada, çağdaşlaşma, modernleşme ya da aydınlanma dediğimiz bütün düzenlemelerin arka planında öncelikle eğitim-öğretime yönelik iyileştirmelerinin olduğu görülmektedir. Sabahattin Ali'de Anadolu coğrafyasının farklı iklimlerinde yaşamış bir yazar olarak, özellikle hikâyelerinde memleketin çözülmesi gereken en önemli problemi olarak gördüğü "eğitim” üzerinde durmakla kalmaz, bilginin yeniden üretilmesi, değerlendirilmesi ve üretilen yeni bilgiyle yeni bir dünya/insan oluşturulması noktasındaki çabalarıyla dikkati çeker. Sabahattin Ali, hem Osmanlı ve Cumhuriyet dönemini hem de Cumhuriyet sonrasında batı uygarlığını yerinde tanıma firsatı bulduğu için, bir taraftan yaşadığı/yurt tuttuğu coğrafyanın bir taraftan da batı dünyasının; kültür, edebiyat, eğitim sistemi ve medeniyetini yakından kavramış, karşılaştırma yapmak imkânını bulmuştur. Bu makalede de, 1930'lu yıllarda Türk hikâyeciliğine gerçekçi bir soluk getiren Sabahattin Ali'nin, eğitimle ilgili problemlere nasıl yaklaştığı ve bu problemleri nasıl ifade ettiği ortaya konulmaya çalışacaktır.

\section{Anahtar sözcükler: Sabahattin Ali, Köy, Anadolu, Eğitim, Öğretmen}

Abstract: The role of education in the definition of man and as an individual is indisputable. Moreover, in all civilized nations, education is regarded as one of the important dynamics of progress and development. Based on this significance, it is also known that western nations, especially those defined by the word "civilized", have organized and passed on education and training activities, long before industry and technology activities, and, it is seen that worldwide, in the background of all the regulations that we term enlightenment or modernization, are primarily educational-teaching improvements. As a writer who lived in the different climates of Anatolian geography, Sabahattin Ali' stand on the "education problem", which he describes in his stories as the most important problem of the country. He draws attention to the efforts at evaluation, the re-production of knowledge and the creation with this knowledge of a new world. Sabahattin Ali, who can also be regarded as a good teacher and man of opinion, finds the opportunity to recognize the concern with culture, literature, the education system and civilization of both the Ottoman and the Republican periods and western civilization. This article attempts to show how Sabahattin Ali, who brought a realistic breath to Turkish narrative in the 1930s, approached the problems related to education and how he expressed these problems..

Keywords: Sabahattin Ali, Village, Anadolu, Education, Teacher

\footnotetext{
* Dr. Öğr. Ü., Balıkesir Üniversitesi Necatibey Eğitim Fakültesi Eğitim Bilimleri Bölümü, Balıkesir. yergunes55@outlook.com
} 
Giriş

İnsanın dünyayı tanımasında, bir birey olarak biçimlenmesinde ve edindiği birikimle içine doğduğu dünyaya katkı sağlamasında, eğitimin rolü tartışılmaz bir gerçektir. Kaldı ki, bütün uygar uluslarda, eğitim; ilerlemenin, kalkınmanın ve yaşanabilir yeni bir dünya yaratmanın önemli dinamiklerinden biri olarak kabul edilmektedir. Bu önemine dayalı olarak, bugün "uygar" kelimesiyle tanımladığımız batılı ulusların, sanayi, teknoloji faaliyetlerinden çok önce eğitim ve öğretim faaliyetlerini düzenledikleri ve hayata geçirdikleri de bilinmektedir.

Bu bağlamda, tüm dünyada, çağdaşlaşma, modernleşme ya da aydınlanma dediğimiz bütün düzenlemelerin arka planında öncelikle eğitim-öğretime yönelik iyileştirmelerinin olmasına rağmen, Osmanlı İmparatorluğu'nda da, yıllar içerisinde işlevini yitirmiş ve görevini yerine getiremeyen kurumlarının çağın ihtiyaçlarına göre yeniden düzenlenmesini amaçlayan pek çok çabanın, yeniden düzenlenme noktasında en gerekli nokta olan "eğitim"i ihmal etmiş olduğu da bilinmektedir. Ergüneş'in ifadesiyle, sözü edilen düzenlemelerde, eğitimle ilgili herhangi bir hedef öngörülmemiş olsa da, çok kısa sürede yapılan iyileştirmelerin istenilen sonucu vermediği ve yapılan iyileştirmelerin eğitim temelli olması gerektiği anlaşılmıştır. Açık bir şekilde ifade edilemese de, toplumsal hayatı yeniden tanzim çabalarının başarıya ulaşmasının yolunun bilgili bir toplum ve yeni bir aydın tipi oluşturmaktan geçtiği ortadadır. Osmanlı, çöküşün önemli nedenlerinden biri olarak, eğitim kurumlarının kendi içine kapanmasını ve pozitif bilimlere ait mantıktan uzaklaşması olduğunu fark etmiştir (Ergüneş 2014, 122). Bu eksikliğe, savaş meydanlarında üstünlüğü elden bırakmamak için teknoloji ithal eden bu dünyanın, bu teknolojiyi üretecek argümanlar aramaması da eklenebilir. Korkmaz'a göre, eğitim kurumları da kendisinden beklenen bu değişimi meydana getirebilecek şartlara hazır değildir. Özellikle medreselerde akli ve nakli ilimleri olduğu gibi tekrarlayan bir anlayış hâkimdir (Korkmaz 2006, 18). Engelhardt ise, "Tanzimat ve Türkiye" adlı eserinde, eğitimin yeniden oluşturulmasının zorunluluğundan söz ederken; memlekette atalet, ilerleme düşmanlığına karşı gelebilecek muktedir ve bilgili memurlar yetiştirmenin yolunun maarifin yeniden ve hızlı bir şekilde yapılandırılmasından geçtiğini ifade etmektedir (Engelhardt 1999, 249).

II. Meşrutiyet Dönemi’nde (1908-1918) de özellikle Emrullah Efendi ve Sat1 Bey'in çabalarıla eğitim sisteminin yenileştirilmesi konusunda önemli adımlar atılır. Hayta ve Ünal'ın tespitiyle, bu dönemde birçok yeni okul açılmış, eski okullar önemli ölçüde 1slah edilmiştir. Orta öğretimde gelişmeler yaşanmış, rüştiyeler orta öğretimden ayrılarak ilköğretime dâhil edilmiştir. Orta öğretimde yabanc1 dil öğretimine önem verilmiş, bu bağlamda Fransızca ön plana çıkarılmıştır. Ayrıca kızların eğitimi için önemli adımlar atılmıştır (Hayta \& Ünal 2003, 208).

Tanzimat ve ardından Meşrutiyet yıllarında millî ve çağdaş bir seviyeyi yakalama çabalarının sürmesine rağmen, gerek I. Dünya Savaşı ve gerekse Milli Mücadele Yılları arzulanan eğitim politikalarının hayata geçmesini bir süreliğine ertelenmesi zorunluluğunu doğurmuştur.

Millî Mücadele'nin kazanılmasının ardından Cumhuriyet'in ilan edilmesi, özellikle Türk inkılâbının başarısının eğitim alanındaki başarıya bağlı olduğu gerçeği, eğitimin yaygınlaşması ve değişmesi için kararlı ve acil adımların atılmasını zorunlu kılmıştır. Akyüz'ün ifadesiyle: "Dönemin siyasal, ekonomik, hukukî, kültürel değişmeleri gerçekleştirildiğinde toplumun \%10'u bile okur yazar olmadı̆̆ için, bunların kitlelere benimsetilmesi ve kökleşmelerinde eğitimin oynayabileceği rol her zamankinden fazla anlaşılmış ve eğitime bu nedenle önem verilmiştir" (Akyüz 2008, 327).

$\mathrm{Bu}$ amaçla eğitim ve öğretimin ilkokuldan yükseköğretime kadar olan her alanında köklü çözümlere gidilmiştir. Bu çözümlerin içerisinde en göze çarpanlardan biri de Köy Enstitüleri tecrübesidir. Aysal'a göre, 1935 yılına gelindiğinde ülke nüfusunun yüzde sekseninin yaşadığ 1 köylerde okul sayısı yok denilecek kadar azdır, bu okullara kentlerden gönderilen öğretmenler, 
köylerde tutunamamakta ve başarılı olamamaktadır. Köyde yaşayanların problemi sadece okuryazarlık değildir, bulaşıcı hastalıklarla savaşamamakta, üretimini ilkel yöntemlerle yapmaktadır. Cumhuriyetle birlikte girişilen köye hizmet çabaları; ya köylünün beklentilerine uymadığı ya da becerilemediği için yarım kalmıştır. Başarı için köylünün dilinden anlayan yeni bir aydın tipine gereksinme vardır. Bu da köylünün kendi içinden çıkabilecektir (Aysal 2005, 278).

Toprak'ın tespitiyle, Atatürk bir yandan bilgisizliği ortadan kaldırmaya uğraşırken, diğer yandan da toplumsal ve ekonomik hayatta etkin bir şekilde yer alabilmek ve toplumsal yaşamı verimli kılabilmek istemiştir. Bu yüzden eğitim sisteminin temelini zorunlu olan ilk bilgileri uygulamalı bir biçimde verme metodu oluşturmalıdır. Atatürk uygulamalı eğitimi, Türk eğitim sisteminin temeli olarak görmüştür. Uygulanacak olan eğitimin işe yarar, üretici ve hayatta başarılı olacak kuşaklar yetiştirilmesini arzu etmektedir (Toprak 2008, 53).

Bu düşünceyle, 3803 sayılı Köy Enstitüleri Kuruluş Kanunu 17 Nisan 1940 tarihinde Türkiye Büyük Millet Meclisi'nde kabul edilmesiyle yürürlüğe girer ve köye göre öğretmen yetiştirmenin son aşaması da başlamış olur. Bu tarihten itibaren kurulan Köy Enstitüleri'nin sayıs1 en son 1948'de kurulan Van-Erciş okuluyla 21'e ulaşır (Yiner 2012, 310). Enstitülerden mezun olan öğretmenlerin köylere dağılmasıyla birlikte, Toprak'a göre, köyler ekonomik ve toplumsal anlamda canlanmaya başlamış ve köyler, gelişme güçlerinin farkına varmışlardı. Öğretmenlerin köylere ulaşmasıyla Anadolu aydınlanmaya başlamıştır. Böylece köylerden başlayan gelişme giderek tüm yurtla bütünleşebilecektir (Toprak 2008, 88).

\section{Sabahattin Ali ve Aydınlığın Geldiği Ocak: Ĕgitim ve Öğretim}

Cumhuriyet sonrası dönemde, devirle ilgili endişeleri kavramış ve eğitim bağlamında bu endişeleri ifade eden önemli isimlerden biri de Sabahattin Ali'dir. Özellikle hikâyelerinde sadece memleketin en önemli problemi olarak gördüğü "eğitim problemi” üzerinde durmakla kalmaz, eğitimle kazanılan bilginin değerlendirilmesi, yeniden üretilmesi ve üretilen bu bilgiyle yeni bir dünya oluşturulması noktasındaki çabalarıyla da dikkati çeker. Sabahattin Ali, hem Osmanlı ve Cumhuriyet dönemini hem de Cumhuriyet sonrasında batı uygarlığını yerinde tanıma firsatı bulduğu için, bir taraftan yaşadığı/yurt tuttuğu coğrafyanın bir taraftan da batı dünyasının; kültür, edebiyat, eğitim sistemi ve medeniyetini yakından kavramış, karşılaştırma yapmak imkânını bulmuştur.

1907 'de, bugün sınırlarımızın dışında bulunan Gümülcine'de doğmuş, çocukluğu Edremit'te geçmiş ve farklı sebeplerle Anadolu coğrafyasının farklı iklimlerinde yaşamış bu Anadolu çocuğu, ilkokulun ardından Balıkesir Öğretmen Okulu'nda beş yıl parasız yatılı olarak okumuş, 1926'da İstanbul Öğretmen Okulu'ndan mezun olmuştur. 1927'de Yozgat'ta bir y1l öğretmenlik yapan Sabahattin Ali, Yozgat günlerinin ardından Maarif Vekâleti'nin yabancı dil öğretmenleri yetiştirmek için Avrupa'ya öğrenci gönderme sınavını kazanarak Almanya'ya gider. Dört yıl süren eğitiminin ardından ülkesine dönerek çok sevdiği öğretmenliğe, liselerde Almanca öğretmeni yaparak devam eder. Yazdığı bir şiirin Atatürk'e hakaret olarak gösterilmesi üzerine hapisle cezalandırılan Sabahattin Ali, 29 Ekim 1933'te Cumhuriyetin Onuncu Y1lı münasebetiyle çıkan af kanunundan yararlanarak özgürlügüne kavuşur. Bu olaydan sonra öğretmenliğe dönmek istemiş fakat mahkûmiyeti nedeniyle memuriyeti iptal edilmiştir. Ancak daha sonra yeniden başvurusu üzerine Maarif Vekili Hikmet Baybur tarafından imzalanan dilekçesiyle öğretmenliğe yeniden dönmüştür. Birkaç kez siyasi sebeplerle hapse atılan Sabahattin Ali, 1948 yılında yurt dışına kaçmaya çalıştığı sırada öldürülür.

Sabahattin Ali'nin eğitime dair düşünceleri iki ana başlık altında okunabilir. Bunlardan birincisi batının ulaştığı bilgileri alarak bunlardan faydalanmak ve özellikle köhnemiş eğitim sistemini yeniden tanzim etmek ve düzenlemek gerekliliği. Kaldı ki bu ısrar da tesadüfî değildir ve önemli bir ihtiyaçtan doğmaktadır. Osmanlı eğitim sistemi, onbeşinci yüzyılın ortalarından 
itibaren akla dayanan pozitif ilimlerden uzaklaşmağa başlamış ve aklın, eğitim kurumlarından kapı dışarı edilmesi, bu kurumların bilgisizliğin, ezberciliğin, şekilciliğin ve kendi kendini tekrarın öne çıktığı kurumlar haline gelmesine neden olmuştur. Bu durumun bir sonucu olarak, ilerlemenin ve aydınlanmanın; akla, mantığa ve gözleme dayandığı unutularak, sadece ezberlenen bilgilerin ezberletilmesi ve tekrarlanması düşüncesine dayanan yeni bir sistem ortaya konulmuştur. Buna karşılık aynı yüzyılda, daha önce reddettikleri aklı ve pozitif bilimleri yeniden keşfeden Avrupa, pozitif bilimlerin 1şığında yeni tekniğe bağlı bir eğitim ve öğretime geçer. Avrupa'nın yeni ve çağdaş bir eğitim sistemiyle aydınlığı yakalamasına karşın, yaşadığımız coğrafya, bu yeni, teknik, eğitim ve öğretimden uzak kalışlarıyla etkisi bugüne kadar devam eden problemlerle karşı karşıya kalmışlardır

Bir toplumun hayata bakış ve hareket tarzını değiştirmenin yolunun öncelikle eğitim sistemini değiştirmekten/yenilemekten geçtiğini fark eden Sabahattin Ali, yaşadığı dönemde Batı'daki gelişmelere yakından şahit olmuş ve arzu ettiği bir aydınlanmanın gerçekleşebilmesinin yolunun eğitim ve öğretim sisteminin tamamen değiştirilmesinden geçtiğini anlamış ve çalışmalarını bu alana adamıştır. Özellikle "ilköğretim"in toplumu yeniden düzenlemenin ilk basamaklarından biri olduğunu kavradığı, hikâyelerinden de anlaşılan Sabahattin Ali, özellikle buralarda meydana gelecek değişimin toplumsal hayatın uygarlık ve ilerleme yolunda önemli mesafeleri aşmasına da katkı sağlayacağını ifade etmektedir.

O halde, O'nun sözünü ettiği değişim, sadece devleti değil aynı zamanda küçük ölçekte bireyleri ve daha büyük bir ölçekte toplumu felakete gidişten kurtaracak en önemli yoldur. Elbette Sabahattin Ali'nin eğitimden anladığı, herkesin sadece okuyup yazması demek değildir. Aksine bunu bir hayat biçimi, alışkanlık haline getirmek gerekir. Bu yüzden çağın en önemli meselelerinden biri budur. Bunu halletmeden diğer sorunları çözümlemenin imkânı yoktur. $O$ halde Avrupa uygarlığı seviyesine varma ve geleceği garanti altına alabilmenin temel şartlarından biri de iyileştirilmesine ve yeniden düzenlenmesine muhtaç olduğumuz eğitim sistemidir. Akıl ve düşünce olarak ilerleyen eğitimciler, bütün toplumu ilerletecektir.

\section{Yazarın Hayal Ettikleriyle Yaşadıkları Arasındaki Fark: Anadolu'da Eğitim Problemi}

Anadolu, Milli Edebiyat devrinde keşfedilmiş ve kırık kalbi yeniden kazanılmıştır. Bu döneme kadar İstanbul'un dışına neredeyse çıkmamış memleket algısı, Türkçülük hareketinin kendisini sadece siyasî bir çerçevede sınırlanmayıp "halka doğru yönelişi" ile birlikte özellikle edebiyat alanında millî kaynaklara dönüşü gerekli kılmıştır. 1911 'de, Yeni Lisan Hareketi ile dilin içinde yeni bir dünyaya aralanan kapı, halka doğru yönelişi ve edebiyat alanında milli kaynaklara dönme düşüncesini sanat alanına taşır. Bu yöneliş Mütareke döneminde arkasına Memleketçilik ve Türkiyecilik gibi adlarla kavramsallaştırılan bir düşünüşü de alarak Cumhuriyet dönemine kadar devam edecektir.

Cumhuriyet sonrasında da "halkçılık prensiplerine" uygun olarak memleket gerçeklerinin dile getirilmesi olanca hızıyla devam eder. Cumhuriyet sonrası bir devlet politikası olarak da köye yönelme; köyün/köylünün önem kazanması ve "yeni edebiyatın asıl ilhamını halkın ruhundan alması" gerektiği düşüncesi, Anadolu'yu başlangıç noktası olarak alan eserlerin yazılmasını sağlamıştır. Gerçi bu eserler başlangıçta Anadolu'nun zorluklarla dolu hayatını yansıtmaktan çok, romantik bir algıyı yansıtmaktan öte gidememişlerse de yeni bir başlangıç olması bakımından yol açıcı olmuşlardır. Ahmet Oktay'ın "romantik köycülük mitosu”(Oktay 1993, 122) olarak tanımladığı bu tavırda, Sabahattin Ali'nin de hikâyelerinde sık sık temas ettiği/ vurguladığı, sanatçının "muhitini” tanımamasının rolü büyüktür.

1930'lu yıllarda Anadolu'yu içerden bir bakışla dile getiremeyen yazarların aksine Sabahattin Ali, köy gerçekliğini ve bu gerçekliğe ait problemleri "gerçekçi bir ses"le getirmiştir. Bu bağlamda, "Ses" hikâyesinin kahramanı Ali’nin "Ben o odada bir türlü sesimi bulamadım" 
sözleri, Sabahattin Ali’nin, kendisinden öncekilerin bulamadığı bir sesin peşine düştüğünün de bir delilidir. Gümülcine'de doğmuş, çocukluğu Edremit'te geçmiş ve farklı sebeplerle Anadolu coğrafyasının farklı iklimlerinde yaşamış bu Anadolu çocuğu, diğerlerinin aksine Anadolu'dan daha dün geldiğini unutmadan, gözlerini dört açarak bu coğrafyada yaşananları izlemeye/ gözlemeye çalışır. Sabahattin Ali’ye göre sanatın tek ve açık bir maksadı vardır: "İnsanları daha iyiye, daha güzele ve daha doğruya yükseltmek. Bireysellikten mümkün olduğu kadar kaçınarak hayata ve muhite dönmek, muhitten pek çok şey almak ve muhite pek çok şey vererek yazmak" (Altınkaynak 33, 2008).

Anadolu'ya, köye, taşraya "muhiti tanıma", "muhitten pek çok şey alma", "muhite pek çok şey verme" bağlamında yaklaşan Sabahattin Ali'nin farklılığı, Anadolu'yu, köyü, taşrayı "tam kalbinden" okuyup onun içinde yaşamaya gayret etmektir. Şimdiye kadar ona kıyıdan bakanlar, orada yaşanan hayatın donmuş, sıradan olduğu gibi yanlış bir düşünceye kapılmışlardır. Hâlbuki onun içine girildiğinde, orada yaşayan/yaşanan hayatın ve insanların tutkuları, acıları, çarpıcı maceraları olduğu net bir şekilde görülecektir.

Sabahattin Ali'ye göre, sanatçı hangi şartta olursa olsun insana inanmalıdır. Çünkü gelecekte olmasını arzu ettiği hayatı bu inanç gerçekleştirecektir. Tanpınar'ın da ifade ettiği gibi, insanı ve hayatı sadece yabancı adeselerin tuttuğu 1ş1klar altında görmek ya da realitesine hiç bakmadan sadece zihnin bir mahsulü gibi yaratmakla sonuç elde etmek mümkün değildir (Tanpınar 1993, 57). Bu bağlamda, 20’li yaşlardan itibaren öğretmenlik yapmış, üstelik mesleğini çok seven Sabahattin Ali, 1950'lere doğru ilerleyen Türkiye'de eğitimle ilgili problemleri de gerçekçi bir şekilde dile getiren ilk isimlerden biridir. Öğretmenliği süresince kasaba ve küçük şehirlerde yaşamış, köyleri gezmiş dolaşmış ve Anadolu insanını yakından tanıma firsatı bulmuştur Sabahattin Ali. Güneş'in ifadesiyle, Aydın, Yozgat ve Konya'da öğretmen olarak bulunan Sabahattin Ali, o günlere ait gözlemlerden hareketle hikâyeler yazdığ 1 gibi aynı zamanda çevreye ve dönem ilişkin sosyolojik veriler de sunar (Güneş 2017, 111). Kentlerden gönderilen öğretmenlerin, köylerde tutunamamakta ve başarılı olamamakta olduğunu görmüştür. Köyde yaşayanların problemi sadece okuryazarlık değildir, bulaşıcı hastalıklarla savaşamamakta, üretimini ilkel yöntemlerle yapmaktadır. Cumhuriyetle birlikte girişilen köye hizmet çabaları; ya köylünün beklentilerine uymadığı ya da becerilemediği için yarım kalmıştır. Başarı için köylünün dilinden anlayan yeni bir aydın tipine gereksinme vardır. Bu da köylünün kendi içinden çıkabilecektir.

Sabahattin Ali hikâyelerinde sadece eğitim değil aynı zamanda insan güvenmeyen, köyü/kasabay1/kendi muhitini tanımayan eğitimli aydınların da eleştirisi önemli bir yer tutar. Sabahattin Ali’nin "Yarı Münevver" olarak tarif ettiği bu kesim: "Bir meseleyi başından alıp sonuna kadar götüremeyecek derecede uyuşuk oldukları ve 'ideophobie' diyebileceğimiz bir nevi 'fikri faaliyetten korkma' illetine tutulmuş bulundukları için yanlarında her hadise hakkında hazır birer hüküm reçetesi taşırlar" (Sabahattin Ali 2007, 111-112). Yazara göre, medeni bir ülkede, köylü, kentli, aydın ve halk, devlet hizmetlerinden yararlanma hususunda eşit haklara sahiptir. Ancak Anadolu'ya çıkıldığında bu durumun tam tersine olduğu görülür. Köylüye ilgi gösterilmez, aydınlar onları küçümser. Kaldı ki, Anadolu'yla aynı dili konuşamayan aydınların, köyü ve köylüyü kavraması, anlaması da mümkün değildir. "Asfalt Yol" hikâyesinde: "Köylüler kendi dilleriyle konuşanları anlamakta gecikmiyorlar" (Sabahattin Ali $2005,8)$ derken de bu duruma işaret etmektedir. Köyün ve köylünün dünyasına "çok şeyler vermeye" değil, bu dünyadan "çok şeyler anlamaya" çalışan bir sanatçı duyarlılığı ortaya koymaya çalışan Sabahattin Ali:

"Bir bayramda şehre inmiş birkaç köylünün kırkar kuruş vererek Kerem İle Asl, Hayber Kalesi gibi kitaplar aldıklarını ve bunları köye hediye götürdüklerini gördüm. Kitap hediyesinin asilzadeler arasında bile moda olmadı̆̆ zamanda halkımızın kitaba para vermediğinden 
bahsetmek ayıptır" (Altınkaynak 33, 2008). Derken de, toplumsal ilişkileri, özellikle de köye bakış açısını değiştirmeden Anadolu'nun sorunlarının çözülmesinin imkânsız olduğuna dair inancını ortaya koymaktadır.

1927 tarihli "Bir Siyah Fanila için" adlı hikâyede mülkiyeyi bitirdikten sonra Anadolu'ya kaymakam olarak atanan Ömer'in Anadolu'nun halinden duyduğu hayal kırıklığıyla işini bırakması ve boyacılık yapmaya başlaması anlatılmaktadır. Mülkiyeli Ömer'in şu sözleri, Anadolu'nun o dönemdeki ruhunu dile getirmesi bakımından önemlidir:

"Anadolu'da işsizliğin doğurduğu yegâne iş olan dedikodu, almış yürümüşı̈̈. Mektep muallimi hususi muhasebe memurunu, tapucu müddeiumumiyi, mal müdürü şube reisini çekiştirir, on dakika sonra da kahvede beraberce tavla oynayı garson kizlara sarkintılık etmekten sıkllmazdl... Illkmektep müdürü müfettiş olmak için çalışırdl, çünkü alacă̆ harcırahlarla, çalgılı kahve kızları uğruna girdiği borçları ödeyecekti" (Sabahattin Ali 2007, 118).

Sabahattin Ali, 1928 tarihli, "Komik-i Şehir" adlı hikâyesinde: "Tezek alevinde 1sınan çocuklara bir kerpicin üzerinde oturarak ders anlatmaya çalışan köy muallimlerinden yol ve haber sordu..." satırlarında, ülkenin eğitimin durumuna trajikomik kelimelerle vurgu yapar. Tezek alevinde 1sınan öğrenciler, masası, tahtası, sırası olmayan bir okul. Eğitim ve öğretim kurumlarının Cumhuriyetin ideallerini gerçekleştirmekten uzak, çağdığı bir görünüme sahip olduğunun anlatıldığ 1 bu satırlar, bu yapıyla, ülkenin yeniden dinamik bir hale gelmesinin, bir silkiniş hareketini başlatabilmesinin mümkün olmadığının da açık bir ifadesidir. Bu köylerde yaşayan çocuklar, sokakları kendi talihinden karanlık köylerde binbir güçlükle ve yoksullukla okula gitmektedir. Bu okullarda görev yapan öğretmenlerin kerpiçten başka oturacak sandalyeleri, ders verecek tahtaları bile yoktur.

Sabahattin Ali, 1930 tarihli "Bir Orman Hikayesi" adlı hikayede, "Biz onun dışında da dünya olduğunu bilmezdik bile" ve "Yeryüzünde başka bir şeyin de olabileceğini bilmiyorduk ki memnun olmayalım" ifadeleriyle, orman köylüleri üzerinden eğitimsizliğin trajik sonuçlarına işaret etmeye çalışır. Yıllardır, atalarından öğrendikleri bilgiyle işlerini gören köylülerin hayatı, köye orman işletmecisi olarak gelen bir şirketle birlite alt üst olur. Şirket, köylülere çok daha modern yöntemlerle işletme sözü verir vermesine ama, yeryüzünde kötülüğün de olabileceğini bilmeyen eğitimsiz köylülerin mutluluğunu, huzurunu, sağlı̆̆ını çalmayı başarır. Ormanın köylülerin elinden çıkmasıyla birlikte köylüler sersefil ortada kalırlar: "Delikanl, biz köylü adamlarız. Aklımız çok ilerisine ermez. Şirket bize, bu ormanlart son sistemle işleteceğim, dedi. Belki dopru söylüyordu. Fakat bu işteki geriliğimizden istifade ederek bizi eli bögrründe bırakmak revayıhak mıydı. O bizim cahilliğimizi, zavallılığımızı kesesini doldurmak için bahane yaptı. Kendisiyle at yarıştıramayacă̆ımızı biliyordu. Hiç insaf etmeden hepimizin canına okudu" (Sabahattin Ali 2007, 82-83).

Bir Orta Anadolu kasabasında geçen ve 1932 tarihli "Bir Skandal" adlı hikayede, Sabahattin Ali öğretmenlerin köyde karşılaştıkları güçlüklerin kasabalarda da yaşandığından bahseder. Eğitimci insanlar, hayatı daha dinamik hale getirmek için harekete geçtikleri an, köylerde ve kasabalarda yaşayan nüfuzlu insanlar tarafından engellenir. Bu hikayedeki öğretmen de tıpkı "Asfalt Yol” hikayesindeki meslektaşı gibi kaderin aynı kavşağında buluşur ve çareyi yol göstermek istedikleri toplumun hışmından kaçmakta bulurlar. Hikayenin kahraman1, memleketin münevverlerinden bahsederken pek çok köyde halen okul ve öğretmen olmadığından bahseder: "ve mektep yüz köyün birinde bile yoktur" (Sabahattin Ali 2015, 82). Öyle ki Sabahattin Ali'nin bu tespiti çok da mübalağalı değildir. Korkmaz'a göre, hikayenin yazıldığı yıllarda toplam 40000 mevcudu olan köylerin ancak 3000 tanesinde okul vardır, 37.000 köy 
okulsuz ve yolsuzdur. Köylü nüfusun ancak yüzde ikisi okuma yazma bilmektedir (Korkmaz 1991, 130).

Sabahattin Ali'ye göre aydın, halkın meselelerini çözmek için kafa yoran, düşünen insandır. Ancak Anadolu'daki aydınların böyle bir kaygıları yoktur. Onlar, halktan kopukturlar. "Bir Skandal" hikâyesinde, öğretmen olarak kasabaya gelen Nurullah, millete, vatana dair ezberlenmiş düşüncelerin ötesine geçememiş aydınlarla çatışır, onları eleştirir. Ona göre erkekler belki doktor, belki mühendis, belki avukat, belki muallim olmuşlardır ancak bunu bir fikir ihtiyac1 olarak değil, iyi giyinmek, iyi karın duyurmak, iyi evlilik yapmak için yapmışlardır. Memleketin ihtiyaç duyduğu aydın tipi elbette bu değildir: "Yalnız ekmek parası düşünen ve asıl vazifelerini, tefekkür kabiliyetini tamamiyla unutarak basit birer makine haline giren bu kafalarda akul, saf ve maddiyatın dışına çıkabilmiş akıl, artık lüzumsuz bir şeydi. Münevverlerimizdeki dimağın rolü körbağırsağınkinden daha fazla değildi. Dünyaya, millete, devlete, vatana dair muayyen ve ezberlenmiş fikirleri vardı ve bunları suya sabuna dokunmamasına azamî derecede dikkat ediliyordu" (Sabahattin Ali 2015, 81).

$\mathrm{Bu}$ anlayış, Kutlu'nun ifadesiyle memleketini tanımayan diplomalı cahillerin iş başına getirilmesi demektir. Toplumun değerleri de bu yönde işlemiş, sadece diplomalara bakılarak tayin ve seçme yapılmış, yetenekler araştırılmamıştır (Kutlu 1972, 154). Sabahattin Ali aydınlardan, şehirli ayrıcalıklı sınıflardan bahsederken hep onların cehaletlerini, küstahlıklarını, bencilliklerini, samimiyetsizliklerini, düşük ahlakî değerlerini vurgular. Çoğu zaman, yalanc1lıktan başka özellikleri yoktur. Hiçbir zaman dillerine pelesenk olan şu sözü tekrarlamaktan vazgeçmezler: "Fakat ne de olsa, köylü bizim efendimizdir" ancak gerçek hayatta köylülere asla efendileriymiş gibi davranmazlar. Şehirliler, şehrin her türlü imkânından yararlanırlar. Ama onlarla aynı vergiyi veren köylülerin bu vergi karşılığında aldıkları bir şey yoktur. Hikâye kahramanlarından biri bu gerçeğin altını çizer:

“Köylü verdiğine mukabil ne alır? Yolunu kendi yapmă̆a mecburdur, sokakları zavall talihinden daha karanlıktır ve mektep, yüz köyün birinde bile yoktur. Candarma oralara asayişten ziyade vergi tahsilini temin için gider. Kendimizi aldatmayalım, köylü mütemadiyen vermiş, buna mukabil hiçbir şey almamıştır. Bunlart itiraf etmek bile belki, ĕger bir parça vicdanımız varsa, yediğimiz bir lokma ekmeğin boğazımızda kalmasına sebep olacaktır ve ihtimal vicdanımızın sedasını duymamak için: "Köylü efendimizdir!" gibi cümleler güzel bir morfindir. Fakat hiçbir cümle hakikati değiştirmek iktidarında değildir" (Sabahattin Ali 2015, 81-82).

1935 tarihli "Apartman" hikayesinde ise bir ustanın, evi geçindiremediği için iş bulup on gün bulamadığı sıralarda, zaten sebebini anlamadan iş olsun diye gönderdiği mektepten aldığı ve bir daha da göndermediği biricik evladının hikâyesi vardır. Geçim zorluğu eğitmin önüne geçmiştir (Sabahattin Ali 2014, 54).

Aynı zorluk 1936 tarihli "Arabalar Beş Kuruşa” adlı hikayenin de konusudur. Sekiz yaşlarında zayıf ve minimini bir çocuk akşam, caddelerin en kalabalık zamanında bir köşa başına gelir ve beş kuruşa araba diye bağırarak arabalarını satar. Bir akşam, büyükçe bir otomobilin içinden inen bir çocuk küçük satıcının sesini işitince irkilir. Çünkü bu minimini ve zayıf çocuk, arabadan inen çocuğun sınıf arkadaşıdır. Aralarında şöyle bir konuşma geçer:

"Derslere ne zaman çalışıyorsun?

-Mektepten çılkınca...Iki saat filan çalışıyorum, desrleri yapıyorum. Ondan sonra buraya geliyoruz. Hem gece zaten çalışamam ki. Gaz masrafi çok oluyor" (Sabahattin Ali 2014, 60). 
1936 tarihli ve -Bir Köy Öğretmeninin Anılarından- epigramıla başlayan "Asfalt Yol” adlı hikâyede anlatılan köye ise altı aydır öğretmen uğramamıştır. Pek çok köyde okulun, okulun bulunduğu köylerde öğretmenin olmadığı bir devirde, okulu bulunan bu köye gelen yeni öğretmen üçüncü bir gerçeklikle daha yüz yüze gelir: Ortada, okula gelmesi gereken öğrenciler yoktur. Kahvedeki ihtiyarlar, harmanların hepsinin kaldırılmadığını, bu yüzden çocukların okula gelemeyeceklerini söyler ve öğretmene beş on gün oturup dinlenmesini tavsiye ederler: "İ̧̧lerinden biri muhtarmış. Benden önceki ögretmen gideli altı ayı geçtiğini, o zamandan beri okulun kapalı olduğunu söyledi" (Sabahattin Ali 2003, 8). Bu manzarayı dile getiren yazara göre, medeni bir ülkede, köylü, kentli, aydın ve halk, devlet hizmetlerinden yararlanma hususunda eşit haklara sahiptir. Ancak Anadolu'ya çıkıldığında bu durumun tam tersine olduğu görülür. Köylüye ilgi gösterilmez, aydınlar onları küçümser. Kaldı ki, Anadolu'yla aynı dili konuşamayan aydınların, köyü ve köylüyü kavraması, anlaması da mümkün değildir. Hikâyede, "Köylüler kendi dilleriyle konuşanları anlamakta gecikmiyorlar" (Sabahattin Ali 2005, 8) derken de bu duruma işaret etmektedir. Ancak, öğretmen, köylülerin diliyle konuştuğu için çabuk anlaşırlar. Böylece öğretmen sadece çocukları eğitmekle kalmaz, köylülere de yol gösterir. Hatta köylülerin dış dünyayla bağlantısını sağlayacak bir asfalt yolun yapımına ön ayak olur. Ancak yolu inşa eden müteahhidin işe hile karıştırması ve bürokratların köye ve köylüye olumsuz bakışı gibi sebeplerle öğretmen yenilgiye uğrar, köylüler tarafından dışlanır ve köyden ayrılmak zorunda kalır. Köy, altı ay öncesi gibi yine öğretmensizdir. Köye ne zaman öğretmen geleceği ise belirsizdir.

1937 tarihli "Ses" hikâyesinde bir yolculuk sırasında tesadüfen keşfedilen Sivaslı Ali'nin bir gün dünyaca tanınmış bir opera tenoru olarak Avrupa'da konserler verdiğini hayal eden kahramanımız, onun sınav için Ankara'ya getirilmesine ön ayak olur. Ali, 'opera mugannisi' yetiştirmek üzere sınav yapacak kurumun müdür odasında, çevresindekilerden habersiz, ürkek bir kuş gibi beklemektedir. Bu mekân, geldiği/yaşadığı yere yabancıdır. Bu yabancılığı ve ürkekliği, ayağına dayadığı sazıyla üzerinden atmaya çalışır. Ali, sazını, Ankara'da konaklanan handan 'kırık sazla efendilere çalmak yakışık almaz herhalde' diye düşünerek 'sekiz kâğıt'a almıştır. Onun aklında opera muganniliğinden çok, Ankara'da 'büyüklere' çalacağ 1 bir iki sazdan sonra kapıcılık ya da hademelik gibi bir iş alıp alamayacağı vardır. Ancak, farklı milletlerden oluşan jürinin karşısında, hayatında ilk defa gördüğü kuyruklu piyanoya eşlik edemeyen Ali, sınavı geçemez. Sabahattin Ali'de bu başarısızlığı Ali'nin ağzından şöyle dile getirir: "Ben o odada bir türlü sesimi bulamadım" (Sabahattin Ali 2014, 122).

1937 tarihli "Köpek" adlı hikâyesinde, kentlerde yaşayanların, aynı havayı solumalarına rağmen köylülerden habersiz olduğundan söz ederken, tahsilli bir genç kızın, köylüleri tanımadığını onları sadece kitaplardan okuduğunu yine onun ağzından itiraf ettirir: "Merak ediyorum ayol, ben hiç köylü görmedim ki!" (Sabahattin Ali 2005, 128). Bu hikâyede, hikâye kahramanlarının köy ve köylü hayatı üzerine konuşmalarına sadece kitaptan okudukları ya da kulaktan dinledikleri bilgiler yön verir. Eğitimini Amerika'da tamamlamış genç adamın, ilk defa bir çobanla karşılaşması sırasında kullandığı "İçini yavaş yavaş halkla, köylüyle temas cazibesi saran" ifadesi de aydınları küçümsemektir aslında.

1941 tarihli "Bir Konferans" adlı hikâyede ise diplomalı ama memleket gerçeklerinden uzak aydınların eleştirisi vardır. Bu hikâyede, şehre yakın köylerden birine yeni yapılan okulu açmak için golf pantolonlu, fotoğraf makineli mühim insanlar gelir. Bu insanların arasında Paraguay'da köycülük tahsili yapmış biri de vardır. Aydınlar, firsat bu firsattır diyerek teorik bilgileri köylüye anlatmak için kooperatifçilik hakkında onlara bir konferans verir. Köylüler her ne kadar anlatılanlardan bir şey anlamasa da başlarını anlamış gibi sallayarak misafiri mükâfatlandırırlar. Konuşma bitince odada kalan eski bir öğretmen kendisinin bile bir şey anlamadığını söyleyince, köylülerden biri "Aman beyim, anlamadık diyelim de bir daha baştan 
$m \imath$ anlatsın" cevabını verir. Bu hikâyede, köylünün artık kendisini hedefleyen çalışmaların, sözlerin sadece slogan olarak var olduğunu ve bunlardan artık hiçbir fayda gelmeyeceğini anladığını görmekteyiz. Köylü, kendisinde karşılığı olmayan sözleri bir daha dinleme külfetine katlanmadığı gibi, kendisine her bakımdan yabancı bu nutukçu kesimden "Onu anlamamak" şeklinde gizli bir intikam almaktadır.

1947 tarihli "Bahtiyar Köpek” adlı hikayede, kendisini, "yazacak hiç güzel şey kalmadı mı, hep mi kötü, sakat şeyleri göstereceksin" diye uyaran dostlarının isteğini yerine getirmek içi, artık açlıktan, 1stıraptan değil, rahattan ve tokluktan bahsedeceğim diyerek hikayesine başlayan anlatıcı, çok istese de bu isteği yerine getiremez. Hikayenin girişinde yapar gibi görünse de, bu satırlarda ironinin olduğu açıktır. Oturduğu semtin güzelliklerinden bahsetmeye başlayan anlatıcı bir anda sözü eğitime getirir: "Oturduğum smetin sokakları geniş ve asfalt. Her biri bir fakir çocuğun liseyi bitirinceye kadar olkumasina yetecek masraflarla yetiştirilen bodur çamlar, caddeye gölge vermese bile güzellik veriyor" (Sabahattin Ali 2006, 59) satırlarıyla sözü eğitime getirir.

\section{Sonuç}

Sonuç olarak, Cumhuriyet sonrası dönemde, özellikle eğitim bağlamındaki problemleri/ endişeleri samimi, gerçekçi ve açık bir biçimde ifade eden ilk isimlerden biri Sabahattin Ali'dir. Çok genç yaşlarda öğretmenliğe başlamış, üstelik mesleğini çok seven Sabahattin Ali, öğretmenliği süresince kasaba ve küçük şehirlerde yaşamış, köyleri gezmiş dolaşmış, böylece ülkenin eğitim problemlerini de yakından görme imkânı bulmuştur. Sabahattin Ali, hikâyelerinde bu problemi göstermekle kalmaz, aynı zamanda eğitimle kazandırılacak bilginin nasıl değerlendirilmesi, bu bilginin yeniden üretilmesi ve üretilen bu bilgiyle yeni bir dünya oluşturulması noktasındaki düşüncelerini de ifade eder.

Sabahattin Ali, hikâyelerinde bir taraftan insan güvenmeyen, köyü/kasabay1/kendi muhitini tanımayan eğitimli aydınları da eleştirir. Medeni bir ülkede, köylü, kentli, aydın ve halk, devlet hizmetlerinden yararlanma hususunda eşit haklara sahiptir. Ancak Anadolu'ya çıkıldığında bu durumun tam tersi bir istikamette gelişir. Köylüye ilgi gösterilmez, aydınlar onları küçümser. Kaldı ki, Anadolu'yla aynı dili konuşamayan aydınların, köyü ve köylüyü kavraması, anlaması da mümkün değildir. O halde, Cumhuriyetle birlikte girişilen köye hizmet çabaları; başta eğitim olmak üzere, ya köylünün beklentilerine uymadığı ya da becerilemediği için yarım kalmıştır. Başarı için köylünün dilinden anlayan yeni bir aydın tipine gereksinme vardır. Bu da köylünün kendi içinden çıkabilecektir. 


\section{KAYNAKÇA}

Akyüz Y. (2008). Türk Eğitim Tarihi, 12. Bask1. Ankara 2008.

Altınkaynak H. (2008). Sabahattin Ali, Markopaşa Yazıları ve Ötekiler. İstanbul 2008.

Aysal N. (2005). "Anadolu'da Aydınlanma Hareketinin Doğuşu: Köy Enstitüleri”. Ankara Üniversitesi Türk İnklâp Tarihi Enstitüsü Atatürk Yolu Dergisi 35-36 (2005) 267-282.

Engelhardt, E.P.(1999). Tanzimat ve Türkiye. Çev. Ali Reşad. İstanbul 1999.

Ergüneș Y.(2014). "Türk Ĕgitim Tarihinde Aydınlı̆̆ın Geldiği Ocak: İsmail Gaspıralı ve Eğitim-Öğretim Faaliyetleri”. Ballkesir Üniversitesi Sosyal Bilimler Enstitüsü Dergisi 31(2014) 121-132.

Filiz Ali-Atila Özkırıml1-Sevengül S. (2014). Sabahattin Ali Anılar, İncelemeler, Eleştiriler. İstanbul 2014.

Güneş, M. (2017). Sabahattin Ali'nin Eserlerinin Kaynakları Roman, Hikâye ve Şiirlerinde Biyografik Unsurlar. Ankara 2017.

Hayta N. \& Ünal, U. (2003). Osmanlı Devlet'inde Yenileşme Hareketleri (17. yy Başlarından Yıkılışa). Ankara 2003.

Kerman,Z. (1993). Ahmet Hamdi Tanpınar, Edebiyat Üzerine Makaleler. İstanbul1993.

Korkmaz R. (2006). Yeni Türk Edebiyatı El Kitabl, 3. Baskı. Ankara 2006.

Kutlu M. (1972). Sabahattin Ali. İstanbul 1972.

Oktay A. (1993). Cumhuriyet Dönemi Edebiyatı. Ankara1993.

Sabahattin A. (2007). Markopaşa Yazıları ve Ötekiler. İstanbul 2007.

Sabahattin A. (2015). Kağnı, Ses, Esirler. İstanbul 2015.

Sabahattin A. (2005). Yeni Dünya. İstanbul 2005.

Sabahattin A. (2015). Değirmen. İstanbul 2015.

Sönmez S. (2015). Sabahattin Ali Hep Genç Kalacağım. İstanbul 2015.

Toprak Gül N. (2008). Cumhuriyetin Illk Döneminde Türk Eğitim Sistemi ve Köy Enstitüleri. Yayımlanmamış Yüksek Lisans Tezi. Afyon Kocatepe Üniversitesi. Afyon 2008.

Yiner A. (2012). "Köy Enstitüleri Üzerine Bir Deneme”. The Journal of Academic Social Science Studies International Journal of Social Science 5/4 (2012) 307-317. 